postpartum levels of plasma vitamin A than women who have borne normal children (Gal et al., 1971). The mode of teratogenic action of synthetic steroids and vitamin $A$ is as yet unknown, but the findings reported here suggest that further research should be undertaken into their effect on the reproductive environment.

This work has been supported by the Medical Research Council. We thank the volunteers who participated in this study, and Schering Chemicals Ltd. for providing synthetic steroids.

\section{References}

Briggs, M., Austin, G., and Staniford, M. (1970). Nature, 225, 81. Briggs, M., and Staniford, M. (1969). Lancet, 2, 742 Briggs, M., and Staniford, M. (1969).
Carr, D. H. (1967). Lancet, 2, 830.
Craft, I., and Wise, I. J. (1969). I.ancet, 2, 1138

Dhadial, R. K., Machin, A. M., and Thait, S. M. (1970). Lancet, 2, 20.

Gal, I., Kirman, B., and Stern, J. (1967). Nature, 216, 83.

Gal, I., Sharman, M. I., and Pryse-Davies, J. (1971). Advances in Tcratology, 5. In press

Giroud, A. (1955). Biological Medicine, 5, 44

Goodman, D. S. (1969). American fournal of Clinical Nutrition, 22, 911.

Grangaud, R., Nicol, M., and Desplanques, D. (1969). American fournal of Clinical Nutrition, 22, 991

György, P., Rose, G. F., and Shipiel, R. A. (1947). Archives of Biochemistry, $12,125$.

Kimble, Marion S. (1939). Fournal of Laboratory and Clinical Medicine, 24, 1055.

Laurell, C. B., Kullander, S., and Thorcll, J. (1968). Scandinavian fournal of Clinical and Laboratory Investigation, 21, 337.

Laurence, P. A., and Sobel, A. F. (1953). Journal of Clinical Endocrinology and Metabolism, 13, 1192.

Moore, T. (1957). Vitamin A, Chapt. 36. Amsterdam, Elsevier.

Rogers, W. E. (1969). American fournal of Clinical Nutrition, 22, 1003.

Spellacy, W. N., and Carlson, K. L. (1966). American fournal of Obstetrics and Gynecology, 95,474

Streiff, R. R. (1970). Fournal of the American Medical Association, 214, 105. Woollam, D. H. M., and Millen, J. W. (1960). In Ciba Foundation Sympo

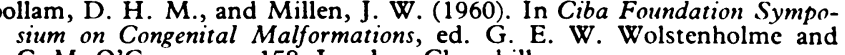
C. M. O'Connor, p. 158. London, Churchill.

Yudkin, S. (1941). Biochemical fournal, 35, 551.

\title{
Action of Thymoxamine on Mydriasis induced by Levodopa and Dopamine
}

\author{
A. S. D. SPIERS, \\ D. B. CALNE, \\ S. D. VAKIL, \\ T. M. FRENCH
}

British Medical fournal, 1971, 2, 438-439

\begin{abstract}
Summary
Eye-drops of levodopa and dopamine induce pupillary dilatation which is inhibited by thymoxamine, an alpha-adrenergic blocking drug. This indicates that the mydriatic action of levodopa and dopamine involves excitation of alpha-adrenergic receptors of the dilator pupillae muscle. Such a conclusion is in accord with the previously expressed suggestion that levodopa is rapidly converted to dopamine, which displaces noradrenaline from adrenergic nerve endings.

The findings that dopamine exerts alpha-adrenergic effects at the periphery may be construed as evidence in support of the view that the hypotensive action of levodopa is mediated via the central nervous system.
\end{abstract}

\section{Introduction}

Levodopa has now been established as the most powerful drug available for the treatment of a considerable proportion of Parkinsonian patients. In some cases, however, the therapeutic action of levodopa is accompanied by adverse effects which include alterations in autonomic function. The most significant of these effects is hypotension, more pronounced in the erect posture, and rarely severe enough to limit

Royal Postgraduate Medical School, London W12 0HS

A. S. D. SPIERS, PH.D., M.R.A.C.P., Research Physician, Leukaemia Unit D. B. CALNE, D.M., M.R.C.P., Lecturer in Neurology, Department of Medicine (Neurology)

S. D. VAKIL, M.R.C.P., Senior Registrar, Department of Medicinc (Neurology)

University College Hospital, London WC1E 6JJ

T. M. FRENCH, M.sC., B.PHARM., Deputy Chief Pharmacist levodopa therapy (Yahr, Duvoisin, Schear, Barrett and Hochn, 1969; Calne, Brennan, Spiers, and Stcrn, 1970; McDowell, 1970). In an attempt to analyse some of these actions on the sympathetic nervous system the response of the dilator pupillae muscle to levodopa and dopamine eye-drops has been investigated. In these studies both drugs have been found to induce pupillary dilatation (Spiers and Calne, 1969; Calne and Spiers, 1970; Weintraub, Gaasterland, and Van Woert, 1970). It has been suggested that this mydriasis is achieved by the release of noradrenaline from adrenergic nerve endings in the iris. In order to investigate this possibility the effect of thymoxamine (an alpha-adrenergic blocking drug) on the mydriatic action of levodopa and dopamine has been studied.

\section{Subjects and Methods}

Subjects.-Twenty-four normal volunteer subjects took part in these investigations-eight were treated with levodopa alone, eight with dopamine alone, four with levodopa and thymoxamine, and four with dopamine and thymoxamine.

Design.-Eye-drops of levodopa or dopamine were instilled into the conjunctival sac of one eye at hourly intervals for six hours. Thymoxamine was given one-and-a-half hours and half-an-hour before administration of levodopa or dopamine. Further doses of thymoxamine were given at hourly intervals two to six hours after starting levodopa or dopamine if the treated eye displayed any mydriasis. All drug administration consisted of two drops. The pupillary diameter was recorded in both eyes by an observer who did not know which eye was being treated. Measurements were made to the nearest $0.5 \mathrm{~mm}$ in artificial light, using the pupillometer of a standard ophthalmoscope.

Drugs.-Levodopa, $1{ }^{\circ}{ }_{0}$ aqueous solution, was buffered with borate to $\mathrm{pH} 7$. Dopamine hydrochloride, $10^{\prime \prime}$ "aqueous solution, was buffered to $\mathrm{pH} 6.5$ with bicarbonate sulphite. Thymoxamine hydrochloride, $0 \cdot 1^{\circ} \mathrm{j}$ aqueous solution, was buffered to $\mathrm{pH} 7$ with borate. 


\section{Results}

Levodopa and dopamine by themselves each produced pupillary dilatation in all patients. Of the four subjects who had thymoxamine before levodopa, two developed and retained miosis throughout the period of observation. In the other two mydriasis developed three hours after the last dose of thymoxamine, but miosis was induced by further instillation of thymoxamine while continuing administration of levodopa. Similar results were obtained in the four patients who were given thymoxamine before dopamine. Two had continuous miosis over the six hours of observation; the other two displayed mydriasis oneand-a-half and two-and-a-half hours after the last dose of thymoxamine. In both the mydriasis was suppressed by giving more thymoxamine while the administration of dopamine was continued.

The results are summarized in the Table, which shows the difference (in $\mathrm{mm}$ ) between the diameter of the pupil in the untreated and treated eye of all subjects at the end of the six-hour period of administration of levodopa or dopamine. A negative value indicates miosis in the untreated eye. It is evident that thymoxamine inhibits the mydriatic response to both drugs (significant to $1 \%$ level).

Action of Thymoxamine on the Pupillary Dilatation Produced by Levodopa and Dopamine in 24 Normal Subjects. Results Expressed as Diameter (in $\mathrm{mm}$ ) of Untreated Pupil Subtracted from Diameter of Treated Pupil Six Hours after Repeated Instillation of Levodopa or Dopamine Eye-drops into Conjunctival Sac. Negative Results Represent Miosis

\begin{tabular}{c|c|c|c}
\hline $\begin{array}{c}\text { Levodopa } \\
\text { Alone }\end{array}$ & $\begin{array}{c}\text { Levodopa and } \\
\text { Thymoxamine }\end{array}$ & $\begin{array}{c}\text { Dopamine } \\
\text { Alone }\end{array}$ & $\begin{array}{c}\text { Dopamine and } \\
\text { Thymoxamine }\end{array}$ \\
\hline \multirow{1}{1.0}{} & -0.5 & 3.5 & 0.5 \\
3.5 & 0.5 & 1.0 & 0.5 \\
3.5 & -0.5 & 1.0 & 0.0 \\
4.5 & -2.0 & 5.0 & -0.5 \\
1.5 & & 1.0 & \\
1.0 & & 1.0 & \\
1.0 & & 5.0 & \\
1.0 & -0.6 & 2.9 & 0.1 \\
\hline Mean & 2.2 & &
\end{tabular}

\section{Discussion}

If it is assumed that the blocking action of thymoxamine is specific for alpha-adrenergic receptors, these results indicate that levodopa and dopamine can exert a peripheral sympathomimetic action by alpha-stimulation. It is commonly found that oral administration of levodopa to Parkinsonian patients results in sympatholytic effects-orthostatic hypotension (Yahr, Duvoisin, Schear, Barrett, and Hoehn, 1969; Calne et al., 1970) and miosis (Spiers, Calne, and Fayers, 1970). One explanation for these observations is that the peripheral sympathomimetic action of levodopa is antagonized by a sympatholytic action mediated via the central nervous system, as suggested by Henning and Rubenson (1970).

It would appear that in the proposed balance between a peripheral sympathomimetic and a central sympatholytic action of levodopa the latter usually predominates. However, this is not always the case. Instead of the usual hypotension occurring in patients receiving levodopa there are occasional cases of hypertension (Cotzias, Papavasiliou, and Gellene, 1969) and other sympathomimetic disturbances such as tachycardia, flushing, and pupillary dilatation (Yahr et al., 1969; Weintraub et al., 1970).

Other possible explanations for the sympatholytic action of levodopa include direct dopaminergic vasodilation of the renal and mesenteric vascular beds (Eble, 1964; McNay, McDonald, and Goldberg, 1965) or dopamine displacing noradrenaline from its storage sites to produce depletion in sympathetic nerve endings (Spiers and Calne, 1969).

Levodopa itself is inactive (Carlsson, 1966), pharmacological effects being produced by its decarboxylated metabolites the catecholamines: dopamine, noradrenaline, and adrenaline. Drugs are available which block the decarboxylation of levodopa to catecholamines and some of these inhibitors are unable to cross the blood-brain barrier. It has been suggested that when such peripheral decarboxylase inhibitors are given with levodopa therapeutic results might be improved by decreasing adverse reactions due to the peripheral formation of catecholamines (Bartholini, Burkard, and Pletscher, 1967). As the peripheral decarboxylase inhibitors do not readily enter the brain, catecholamines can still be formed at this site. Initial clinical reports of this new approach to treatment have been encouraging (Barbeau, 1969; Cotzias et al., 1969). Unfortunately it has been found that hypotension is exacerbated by this combined therapy (Watanabe, Chase, and Cardon, 1970), an observation which affords further support for the view that the sympatholytic action of levodopa is mediated via the central nervous system. This raises the possibility that in patients taking levodopa alone a peripheral sympathomimetic effect may tend to compensate for the central hypotensive action.

This work was supported by the Wellcome Trust. We wish to thank Miss A. Petrie for statistical assistance.

\section{References}

Barbeau, A. (1969). Canadian Medical Association fournal, 101, 791

Bartholini, G., Burkard, W. P., and Pletscher, A. (1967). Nature, 215, 852 alne, D. B., Brennan, J., Spiers, A. S. D., and Stern, G. M. (1970) British Medical fournal, 1, 474.

Calne, D. B., and Spiers, A. S. D. (1970). In L-dopa and Parkinsonism, ed A. Barbeau and F. H. McDowell, p. 311 . Philadelphia, Davis.

Carlsson, A. (1966). In Handbook of Experimental Pharmacology, ed. O Eichler and A. Farah, vol. 19, p. 529. Berlin, Springer.

Cotzias, G. C., Papavasiliou, P. S., and Gellene, R. (1969). New England fournal of Medicine, 280, 337.

Eble, J. N. (1964). Fournal of Pharmacology and Experimental Therapeutics, $145,64$.

Henning, M., and Rubenson, A. (1970). Fournal of Pharmacy and Pharmacology, 22, 553.

McDowcll, F. H. (1970). In L-dopa and Parkinsonism, cd. A. Barbcau and F. H. McDowell, p. 263 Philadelphia, Davis.

McNay, J. L., McDonald, R. H., and Goldberg, L. I. (1965). Circulation Research, 16, 510 .

Spiers, A. S. D., and Calne, D. B. (1969). British Medical fournal, 4, 333. Spiers, A. S. D., Calne, D. B., and Fayers, P. M. (1970). British Medical Fournal, 2, 639.

Watanabe, A. M., Chase, T. N., and Cardon, P. V. (1970). Clinical Pharmacology and Therapeutics, 11, 740.

Weintraub, M. I., Gaasterland, D., and Van Woert, M. H. (1970). New England fournal of Medicine, 283, 120. Yahr, M. D., Duvoisin, R. C., Schear, M. J., Barrett, R. E., and Hoehn,
M. M. (1969). Archives of Neurology, 21, 343. 